TranscUlturAl, vol. 8.1 (2016), 126-133.

http://ejournals.library.ualberta.ca/index.php/TC

\title{
Warning!
}

- The following presentation contains

anecdotal and even biographical statements.

Academic discretion strongly advised.

\section{Travel, Translation and Memory ${ }^{1}$}

Anne Malena

University of Alberta, Canada

Born in Switzerland; took my first step in Sóller, Mallorca

A mind picture through stories

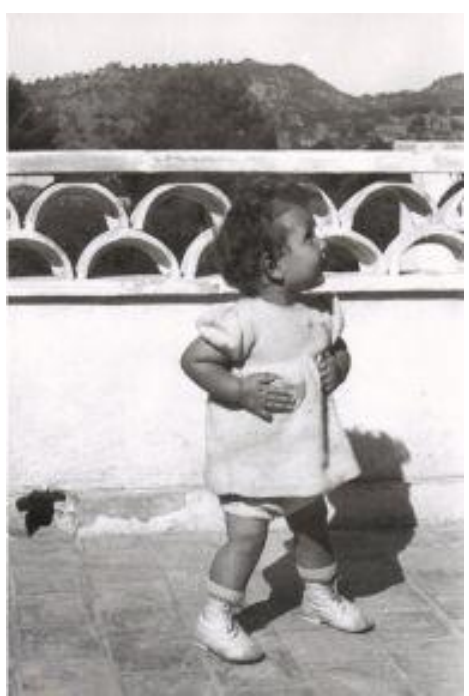

The Adventure of the First Step

Why do we travel? I remember my mother coming from Switzerland every year to spend a couple of weeks with us and get reacquainted with her grandchildren. Shy and struggling with English she would make sure she had her camera with her at all times and took as many shots as her painful lack of spontaneity would allow her to achieve. I realized near the end of her life, while cleaning out her apartment once Alzheimer had forced her into a nursing home, that she had treasured every one of those pictures, carefully labeled them and placed them in photo albums where they had faded over

\footnotetext{
${ }^{1}$ An earlier version of the first part of this essay was presented, along with a looped PowerPoint Presentation, at a panel on travel in the Department of Modern Languages \& Cultural Studies, University of Alberta, on March 1 ${ }^{\text {st }}$, 2013. A draft version of the entire essay, with an upgraded PowerPoint Presentation, was presented at the Translation Readings, part of the celebration of translation during the St. Jerome's Day Conference, in the Department of Modern Languages \& Cultural Studies, University of Alberta, on October 1, 2015.
} 
time along with her memory and her recognition of the dim figures appearing in them. Well, truthfully, I remembered as I was looking at them that I had been annoyed at the time about her devotion to taking pictures rather than trying to enter my children's world and to finally learn through them to live in the moment.

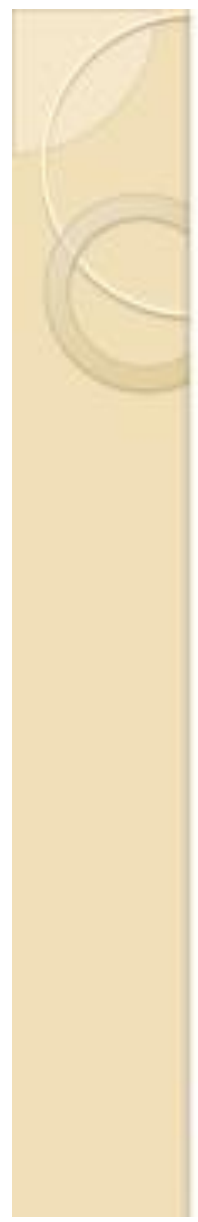

\section{Professional!}

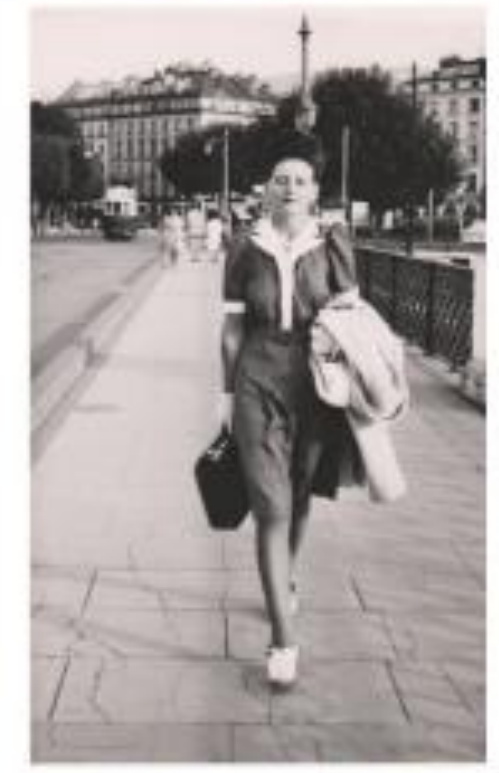

Genève, 1944?, 45?, 46?

Un air de confiance en toi que je n'ai jamais connu
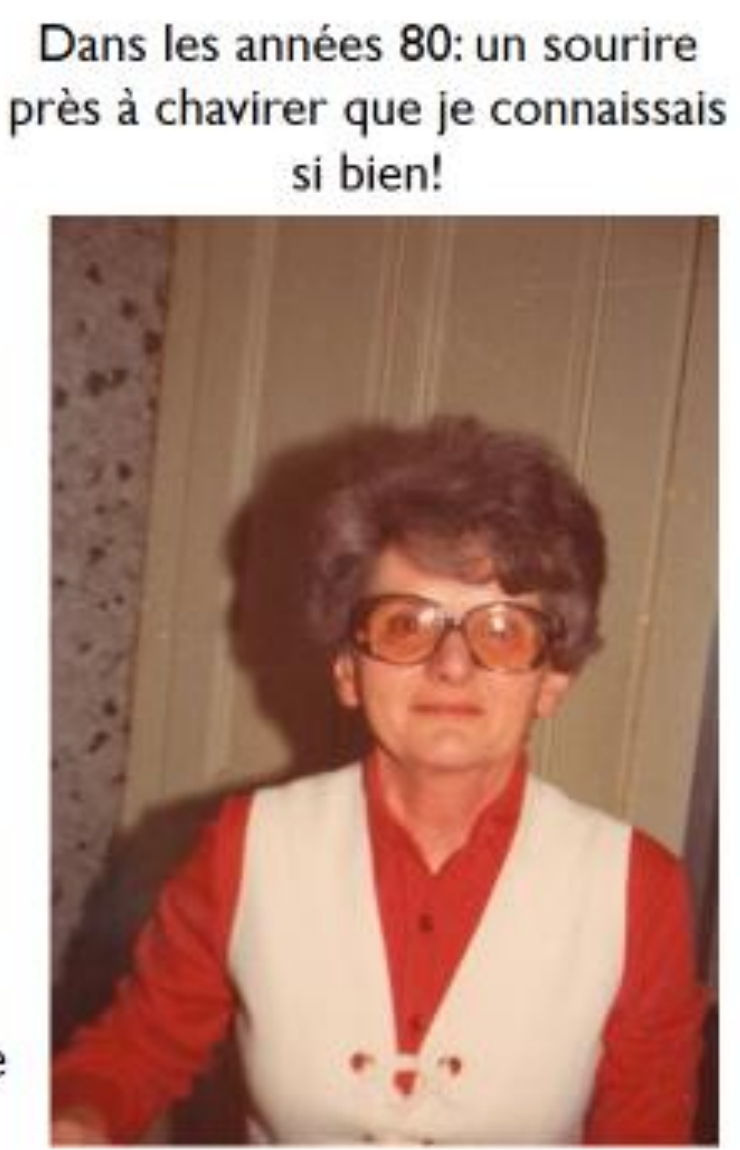

Thinking about this now I wonder whether travel is also a way to connect past and future in a series of present moments, to use our mind like a camera and to seek instantaneous thrills that we immediately commit to memory. If I was writing this in French I could play on this idea of an instant through language since "shot", as in "camera shot", is translated as "instantane". So I felt impatient with a mother whose personality prevented her from being defined as a traveler and in awe of a father who defined himself through traveling and discoveries. The first was very much present and comforting but mostly silent, the second absent the majority of the time but fascinating when present, often choosing an object from his "office" during the evening meal and telling us exciting stories related to it. 

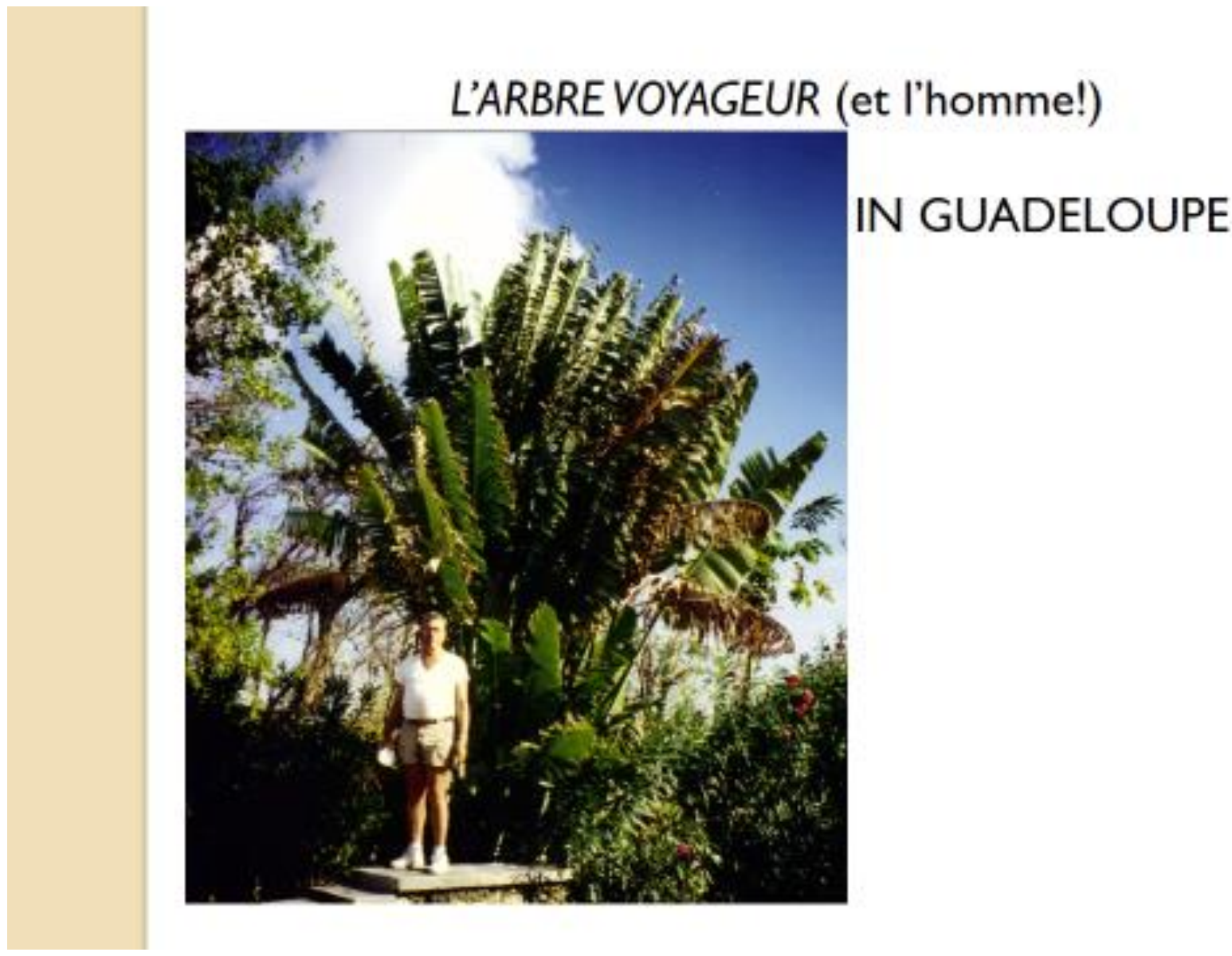

As a young adult I traveled far but I also settled quickly and, although I still imagine traveling a lot, finally go to my childhood dream locations of Tierra del Fuego and Iceland, my desire is not as sharp as it used to be, due partly to my health and partly to the fact that the ease of travel is now rapidly degenerating into a commercial and often uncomfortable enterprise. But I will always carry within me the memory of that desire and I even may some day act on it. My travel memories are the sharpest memories I have. I can recall instantly a street corner in Florence or a zócalo in San Cristobal de la Casas and with it the surrounding noise and the voices of people, often children, I interacted with. The pictures are piled up somewhere in my house or, more recently in my computer but finding the ones I wanted for this text proved to be more difficult than I imagined and often did not correspond exactly to the pictures in my mind.

And I prefer the latter, which is probably why I study literature and culture because my research is a form of travel, a collection of discoveries that I then process and develop like I would a film, with the help of my memory and into memories. I feel about the choice I have made to live my life in a similar way to what my compatriot wrote about travel: "Un voyage se passe de motifs. Il ne tarde pas à prouver qu'il se suffit à lui-même. On croit qu'on va faire un voyage, mais bientôt c'est le voyage qui vous fait, ou vous défait" (Bouvier 11). 
TranscUlturAl, vol. 8.1 (2016), 126-133.

http://ejournals.library.ualberta.ca/index.php/TC

\title{
TRAVEL MEMORIES...
}
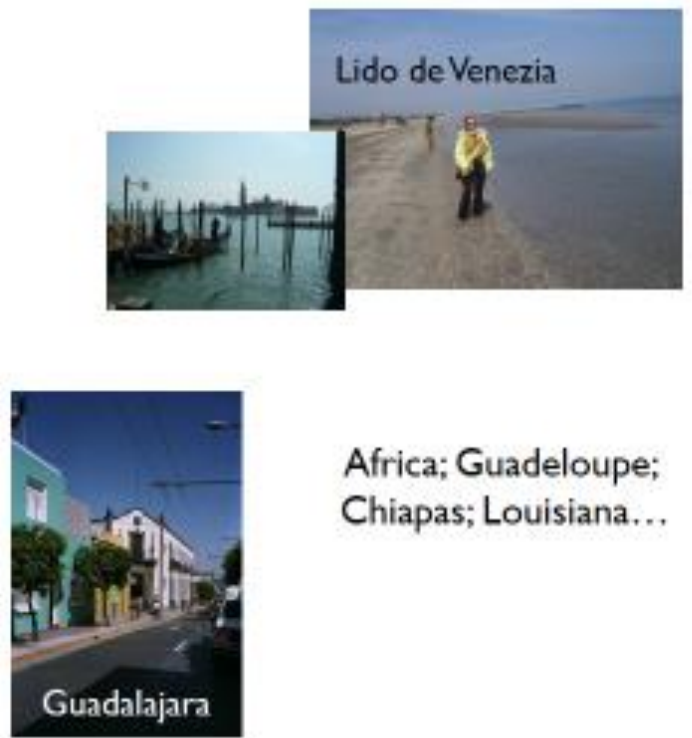

\author{
Africa; Guadeloupe; \\ Chiapas; Louisiana...
}

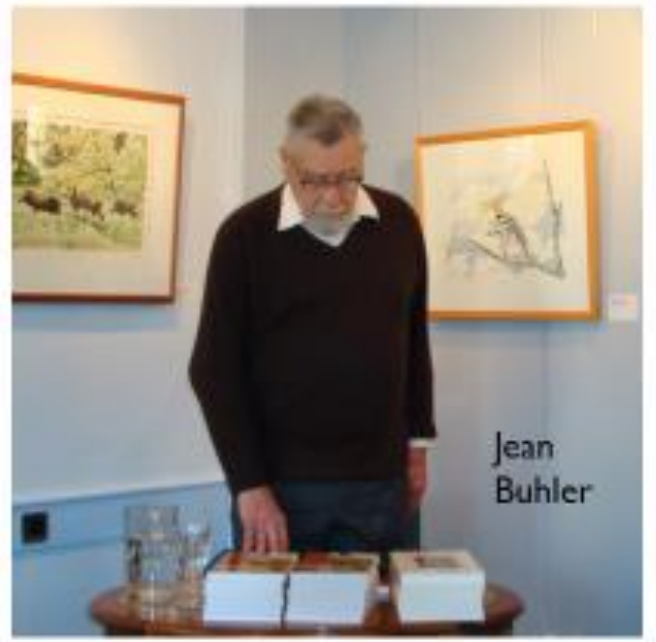

Genetic Influence

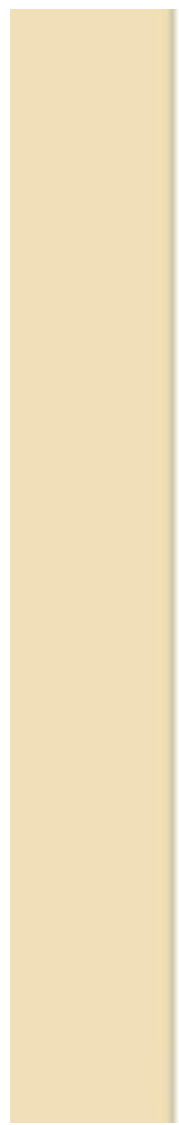

En hommage au grand voyageur qui est mon pere

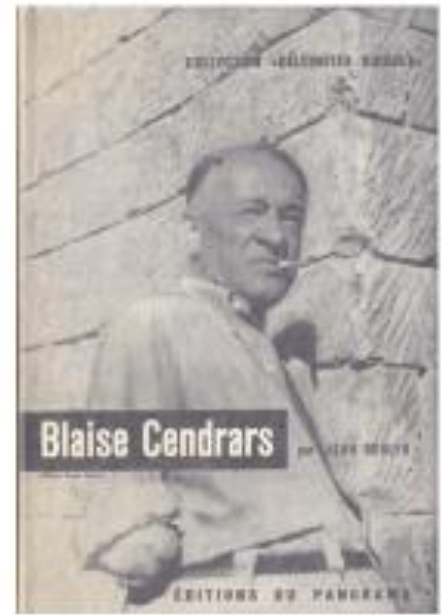




\title{
Les voyages, la mémoire et la traduction
}

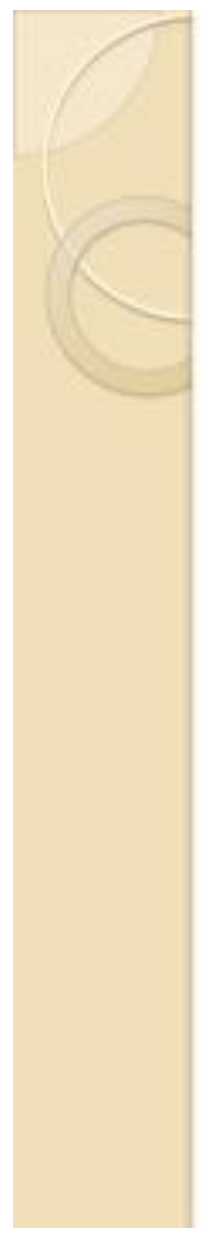

\section{Où a passé maman?}

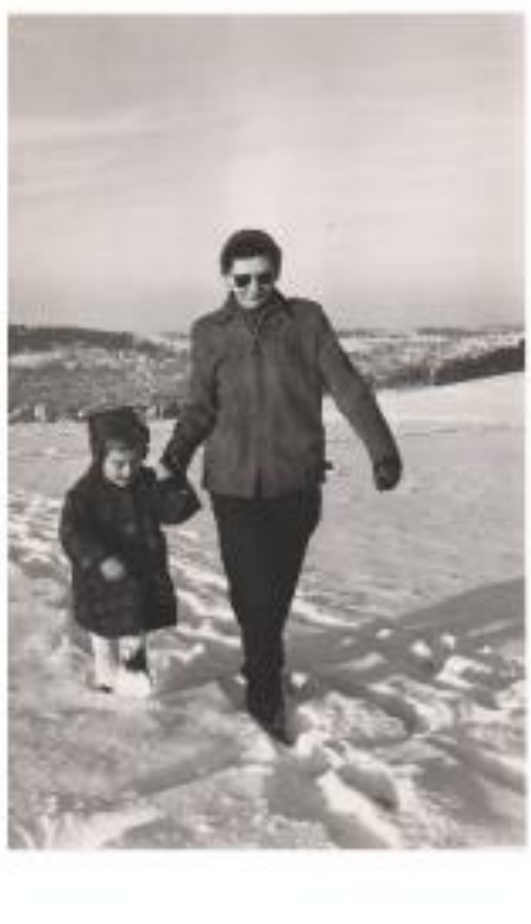

\section{Le souvenir qui s'impose}

\author{
tout à coup!
}

En voulant traduire ce texte et l'adapter au thème «traduction et mémoire », Mnémosyne me pousse dans une autre direction: elle insiste que je parte à la découverte de ma mère, pas telle que je la connaissais, ce dont je crois me souvenir, mais telle qu'elle fut avant de devenir mère. Donc, je commence : Pourquoi voyageons-nous? Je me souviens des visites annuelles de ma mère, venant de Suisse passer deux semaines avec nous et refaire connaissance de ses petits-enfants. Timide et s'exprimant difficilement en anglais, elle n'était jamais sans son appareil de photo et prenait autant de clichés qu'elle pouvait, malgré sa pénible absence de spontanéité. Elle accumulait ainsi des instantanés alors que les instants, ou les occasions de faire de nouvelles découvertes, passaient vite sans qu'elle s'en aperçoive. J'ai compris vers la fin de sa vie, en vidant son appartement après que l'Alzheimer l'avait exilée dans une maison médicalisée, qu'elle chérissait chacune de ces photos, les classait, ajoutait des légendes et les plaçait soigneusement dans des albums où, délaissées, elles s'effaçaient peu à peu, en même temps que sa mémoire et la faculté de reconnaittre les vagues figures qu'elles représentaient. Bon, en vérité, je me suis surtout souvenue de l'irritation que je ressentais, causée par la dévotion qu'elle manifestait pour la photographie au lieu de tenter de pénétrer l'univers de mes enfants et d'apprendre enfin, à travers eux, à vivre dans le moment. 
En réfléchissant là-dessus aujourd'hui, je me demande si le voyage n'est pas aussi une façon de relier le passé et le futur le long d'une série de moments présents, d'utiliser notre cerveau comme un appareil de photo et de rechercher des plaisirs instantanés afin de les confier immédiatement à notre mémoire... et je dévie.... L'espace temporel entre l'instantané et le souvenir s'estompe et, chez ma mère, allait jusqu'à disparaître complètement. Est-ce que cette urgence mémorielle était peut-être un signe précurseur de l'Alzheimer à venir? Une question qui restera sans réponse, mais mon propre désir de voyager, pour ainsi dire, dans la mémoire effacée de ma mère disparue, ne me lâche pas et c'est aussi à travers des photos que je me lance à la recherche de la découverte de cette femme inconnue qui devait devenir ma mère.

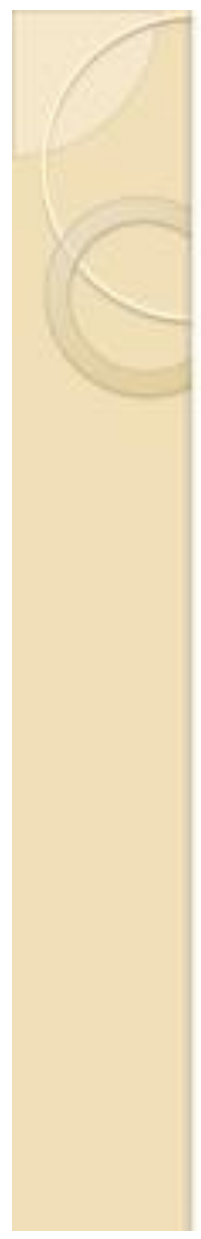

\section{Elle s'impose}

- Jeune et belle!
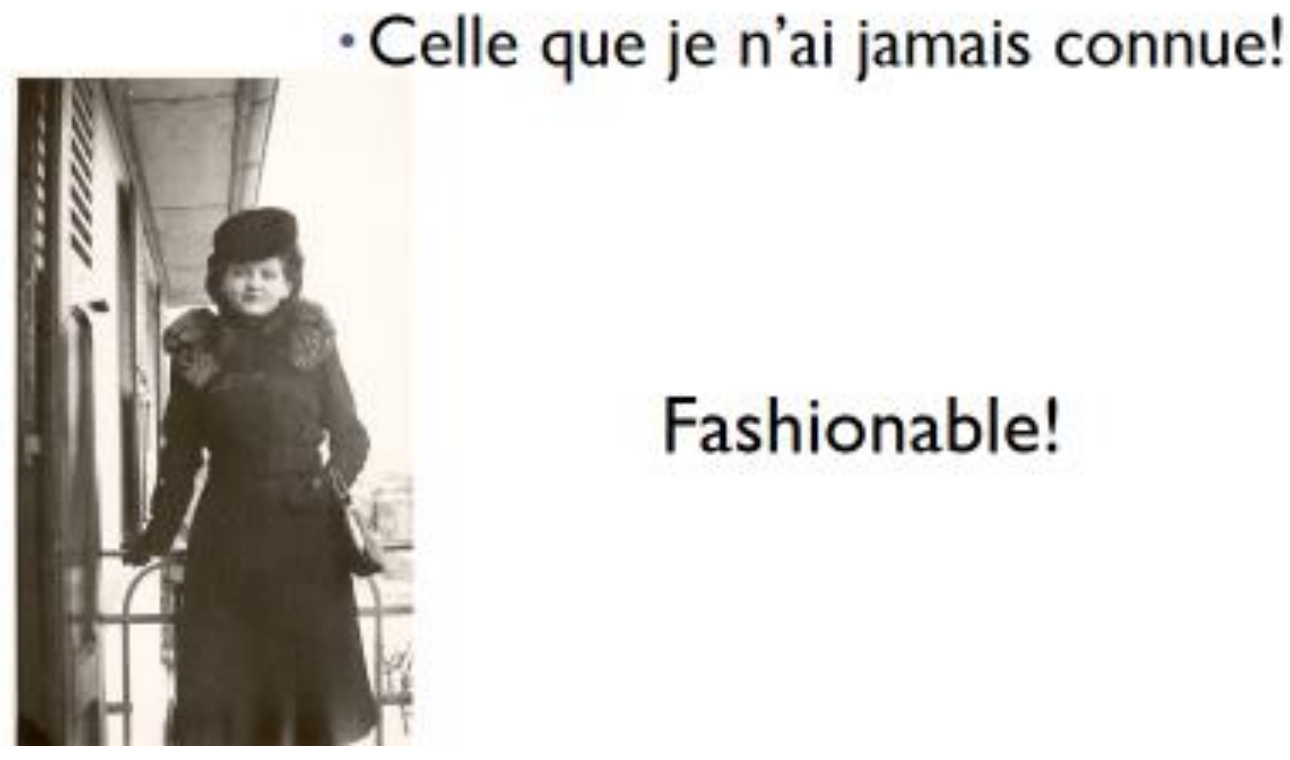

\section{Fashionable!}

Elle semble si jeune, si libre, si belle! Je contemple des images qui suggèrent des flirts, des amies, de la joie, du rire! Je choisis celles que je trouve les plus belles et elles m'aident à composer une histoire tout en forgeant un lien, une continuité entre les versions temporelles d'une seule et même personne. Je réconcilie ces photos pleines d'espoir et d'avenir avec mes images intérieures de larmes, de difficultés, voire de tragédie. 
TranscUlturAl, vol. 8.1 (2016), 126-133.

http://ejournals.library.ualberta.ca/index.php/TC
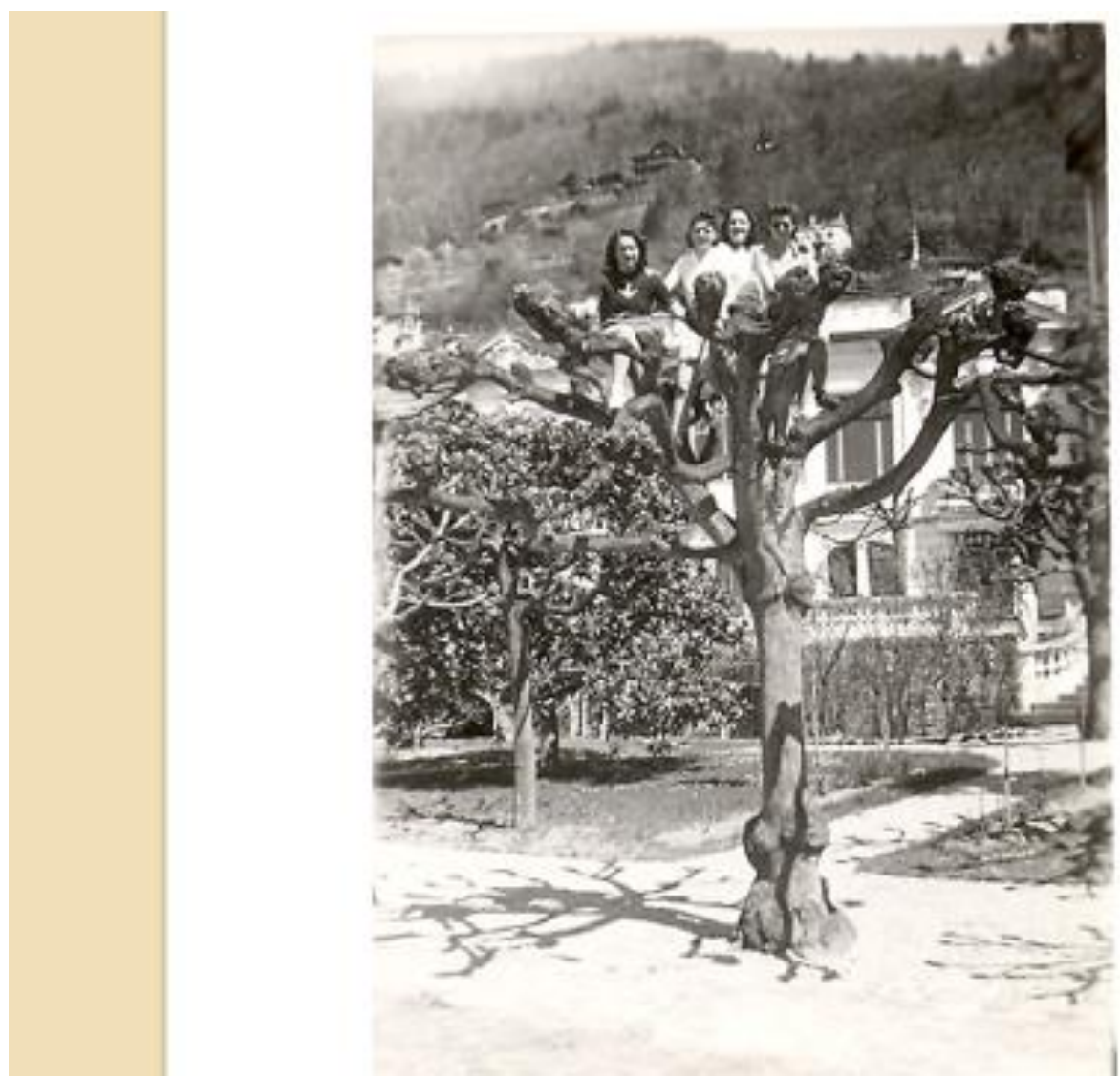

Elle m'avait dit une fois qu'elle se sentait souvent comme une fleur desséchée à laquelle il n'aurait fallu qu'un peu d'eau pour qu'elle revienne à la vie. Je lui ai dit dans une lettre d'adieu que des infirmières lui liraient sur sont lit de mort que j'aurais voulu pouvoir l'arroser, chaque jour, avec amour. Voilà longtemps que je me suis pardonnée de ne pas avoir pu lui rendre la joie de ses vingt ans et aujourd'hui, je suis profondément reconnaissante du voyage dans la mémoire que cet exercice de traduction a facilité tout en me renvoyant une image enfin apaisante de ma maman.

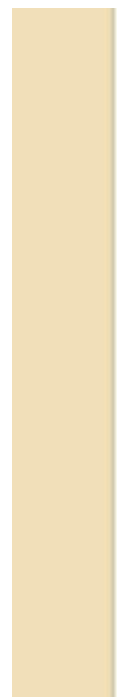

Caribbean Memory during a Canadian Winter

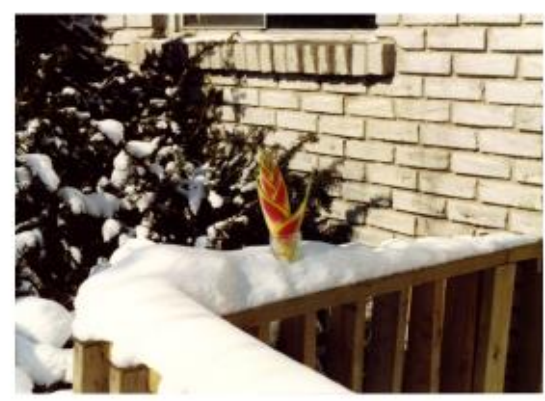

Pour toi maman! 
TranscUlturAl, vol. 8.1 (2016), 126-133.

http://ejournals.library.ualberta.ca/index.php/TC
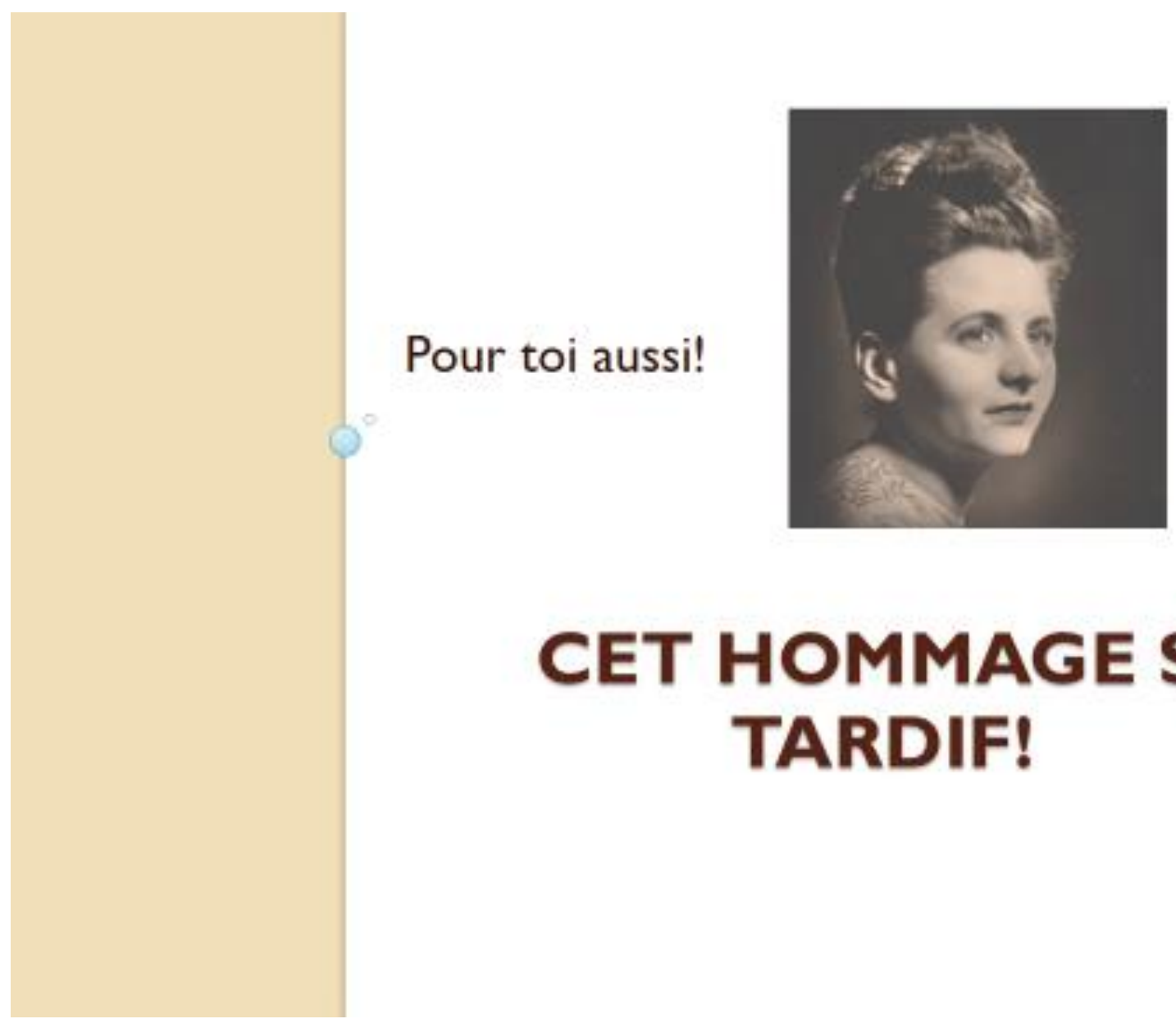

\section{CET HOMMAGE SI TARDIF!}

\section{REFERENCES}

Bouvier, Nicolas. L’Usage du monde. Paris: Éditions Payot, 1992. Print. 